\title{
CP3-8
}

\section{QOL・性機能からみた BPH 治療}

倉敷中央病院

寺井章人

BPH は QOL disease であると広く認識されているが、IPSS、QOL index、BPH Impact Index（BII）などの疾患特異的尺度 のみでは QOL 評価として十分とは言えない。QOL index は排尿状態全般の満足度に関する質問であり、その簡便性から BPH における QOL の代名詞のごとく頻用されているが、そもそも1項目のみでは QOL 評価のツールとしては不十分である上、治 療前後で IPSS と同じ変化を示すことから精神面も含めた QOL 評価とはなっていない可能性がある。BII は排尿状態が原因と なった身体不快感、不安、煩わしさ、活動の制限に関する 4 項目の質問からなり疾患特異的 QOL 尺度として有用であるが、QOL に含まれる様々な領域をカバーしていない。BPHによるQOL 障害および治療による変化を調べるためにはSF-36、EuroQol (EQ-5D) などの包括的健康関連 QOL を含めた評価が必要であろう。Population-based study では下部尿路症状 (LUTS)、中 でも蓄尿症状が強いほど包括的および疾患特異的 QOL 障害の程度が大きいと報告されたが、LUTSは必ずしも BPH が原因と は限らず、また男女とも同様の結果であった。したがって、BPH（=LUTS suggestive of BPH）によるQOL 障害および治療 によるその変化に関しては今後更なる検討が必要である。

BPH と性機能障害はともに加齢に従って増加する。年齢の影響を取り除いても LUTS (中でも蓄尿症状) が強いほど性機能 障害の程度が大きいとの報告があるが、BPH が性機能に直接影響する訳ではないようである。BPH 治療の副作用として性機能 障害が生じる可能性があるが、性機能についてはリビドー、勃起能、射精の 3 者を区別して考える必要がある。TURPはリビ ドーや勃起能にはほとんど影響を与えないが、逆行性射精が半数以上の症例で認められる。逆行性射精をきたした症例では性 的満足感が低下するという報告がある一方で、高齢者では sexual bother は少ないとの報告もある。薬物療法では、finasteride によるリビドー・勃起能低下、精液量減少や $\alpha$ 遮断薬による逆行性射精などがあるが、総じて性機能障害の頻度は低い。

今回の講演では、QOL・性機能からみた BPH 治療を内外の文献をレビューしながら検証したい。

\section{CP3-9}

\section{医療経済から見た BPH 治療}

浜松医科大学泌尿器科学教室

大園誠一郎

$\mathrm{BPH}$ の治療法の選択には、重症度判定を行い、可能な限りその重症度に応じた妥当な治療法を選択することを基本姿勢としている。 しかし、本疾患は病勢の進行が緩徐で、致死的な疾患ではないため、QOL病としての色彩が強いことから、欧米においては治療効果の 追究のみに留まらず、cost performanceについても議論され、治療法選択の根樾の1つとされてきた。

本邦においても、バブル経済崩壊後の逼迫した経済情勢の内において、医療財政も漫然と従来どおりのスタンスでは決して続けてい けない事情が存在している。この深刻化する医療費の增加を抑制する目的で、厚生労働省による診療報酬体系の抜本的見直しの一環と して種々の疾患で包括医療費支払い方式 (DRG/PPS) の導入がなされた。限られた医療資源を有効に活用するには、治療の有効性を医 学的な治療効果のみで判定するのではなく、経済的効率を加味した治療法の全般的な有用性の評価が求められている。言い換えれば、 これまで医療費問題はタブー視されて続けてきたが、まさに、21 世紀の医学と医療のキーワードとして医療経済が挙げられる。

BPH の経济的評価には、費用効果分析（cost-effectiveness analysis）や費用効用分析（cost-utility analysis）などがある。そこで、過 去に治療した $\mathrm{BPH}$ 症例を用いて、各治療法がどの程度の経済効果を示したかを、ガイドラインの判定基準ならびに経済効率を加味して retrospective に検討した。対象症例の多い $\alpha_{1}$ ブロッカー $\alpha$ B) 群と TURP 群を比較すると、IPSSでは治療開始後約 6 力月で TURP 群が $\alpha \mathrm{B}$ 群の効果を上回っていた。また、QOL スコア、Qmax では約 18 力月の時点で TURP 群が $\alpha \mathrm{B}$ 群の効果を上回り、漫然と薬物 療法を続けると経時的に費用が累積し、かえって手術より高価な治療費を要することが明らかになった。目下、「前立腺肥大症治療の経 済効率に関する研究会」による共同自主研究が全国的に進められており、ここから $\mathrm{BPH}$ の重症度や観察期間などの背景因子を統一した 多施設によるデータが示されることが望まれる。

今後、本疾患に対する経済性を含めた QOL の要素を盛り込んだ判定基準により、各種の治療法の有用性の検討を行うことは、本邦の みならず国際的にも要求されている課題である。 